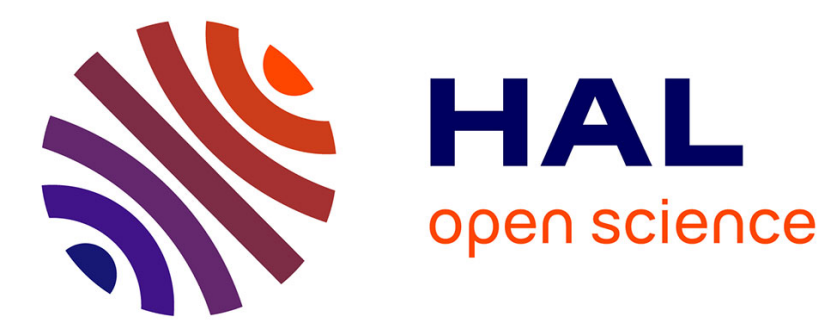

\title{
The effect of environment and structure on creep fatigue crack propagation in a $\mathrm{P} / \mathrm{M}$ astroloy
}

\author{
H. Loyer-Danflou, M. Marty, A. Walder, J. Mendez, P. Violan
}

\section{To cite this version:}

H. Loyer-Danflou, M. Marty, A. Walder, J. Mendez, P. Violan. The effect of environment and structure on creep fatigue crack propagation in a P/M astroloy. Journal de Physique IV Proceedings, 1993, 03 (C7), pp.C7-359-C7-362. 10.1051/jp4:1993756 . jpa-00252174

\section{HAL Id: jpa-00252174 https://hal.science/jpa-00252174}

Submitted on 1 Jan 1993

HAL is a multi-disciplinary open access archive for the deposit and dissemination of scientific research documents, whether they are published or not. The documents may come from teaching and research institutions in France or abroad, or from public or private research centers.
L'archive ouverte pluridisciplinaire HAL, est destinée au dépôt et à la diffusion de documents scientifiques de niveau recherche, publiés ou non, émanant des établissements d'enseignement et de recherche français ou étrangers, des laboratoires publics ou privés. 


\title{
The effect of environment and structure on creep fatigue crack propagation in a $\mathbf{P} / \mathbf{M}$ astroloy
}

\author{
H. LOYER-DANFLOU, M. MARTY, A. WALDER, J. MENDEZ* and P. VIOLAN* \\ ONERA, 29 Avenue de la Division Leclerc, Châtillon sous Bagneux, France \\ * Laboratoire de Mécanique et de Physique des Matériaux, URA 863 du CNRS, ENSMA, rue Guillaume \\ VII, 86034 Poitiers, France
}

\begin{abstract}
The effect of environment and structure on creep fatigue crack propagation in a $\mathrm{P} / \mathrm{M}$ Astroloy has been investigated by performing tests in air and in vacuum at $650^{\circ} \mathrm{C}$ and $750^{\circ} \mathrm{C}$. Complex mechanical and environmental interactions have been revealed at $750^{\circ} \mathrm{C}$ temperature at which the $d a / d N-\Delta K$ relationship obtained in air appears to be highly dependent of the initial $\Delta \mathrm{K}$ values applied at the beginning of the creep-fatigue test. The effect of grain size with smooth grain boundaries appears to be strongly related to environmental effects rather than to creep properties. A serrated grain boundary morphology considerably improves crack growth resistance at $750^{\circ} \mathrm{C}$ under creep-fatigue conditions.
\end{abstract}

\section{INTRODUCTION}

Nickel base superalloys, elaborated by powder metallurgy are used for the manufacturing of turbine discs employed up to about $650^{\circ} \mathrm{C}$. In order to develop new disc superalloys allowing an increase in the temperature capability a better understanding of the relative role of creep, fatigue and oxidation on crack growth processes is necessary. The objective is to identify some pertinent criteria which will permit to select appropriate composition and microstructure.

In this work the behaviour under creep-fatigue loading conditions of a $\mathrm{P} / \mathrm{M}$ Astroloy with the composition Ni-16.4 Co-14.7 Cr-3.9 Al-3.5 Ti-5.0 Mo-0.03 C-0.02 B-0.03 Zr (weight per cent), was investigated at $650^{\circ} \mathrm{C}$ and $750^{\circ} \mathrm{C}$. Crack propagation tests were conducted on SEN $60 \times 13 \times 5 \mathrm{~mm}^{3}$ samples using a $10 \mathrm{~s}$ 300 s - 10s trapezoidal cycle ( 300 seconds dwell time at the maximum tensile level) with a load ratio $\mathrm{R}=0.05$. Crack length was determined by a D.C. potential drop technique and all the specimens were precracked by fatigue in air at $650^{\circ} \mathrm{C}$ with a frequency of $20 \mathrm{~Hz}$. In order to separate the intrinsic properties of the material and the oxidation effects, the creep fatigue experiments were conducted in air and in a high vacuum (pressure $\simeq 2 \times 10^{-4} \mathrm{~Pa}$ ).

\section{TEMPERATURE AND ENVIRONMENT EFFECTS}

The role of temperature and environment was investigated on a material processed with an argon atomized powder compacted by extrusion. This material has a grain size of $20-30 \mu \mathrm{m}$ after supersolvus heat treatment.

\section{Role of temperature}

The $\mathrm{da} / \mathrm{dN}-\Delta \mathrm{K}$ curves obtained in vacuum are reported in Fig. 1 . The increase in temperature from $650^{\circ} \mathrm{C}$ to $750^{\circ} \mathrm{C}$ has a significant effect on the crack growth rates (about 8 times higher at $750^{\circ} \mathrm{C}$ than at $650^{\circ} \mathrm{C}$ ) 
and is accompanied by a modification of the fracture processes from transgranular at $650^{\circ} \mathrm{C}$ to intergranular at $750^{\circ} \mathrm{C}$; that shows the importance of time-dependent damage processes at $750^{\circ} \mathrm{C}$.

\section{Environmental effects}

Fig. 2 illustrates the da/dN- $\Delta \mathrm{K}$ relationships obtained in air and in vacuum at $650^{\circ} \mathrm{C}$. The environment produces a strong acceleration of crack propagation rates especially for the low $\Delta \mathrm{K}$ values (10 times higher in air than in vacuum) associated with a marked modification of the fracture mode which becomes clearly intergranular in air [1].

At $750^{\circ} \mathrm{C}$ the effect of environment is more complex (Fig. 3) ; the $\mathrm{da} / \mathrm{dN}-\Delta \mathrm{K}$ relationship in air can be represented by two different curves according to the initial $\Delta \mathrm{K}$ conditions : in vacuum

- when test in air is started at $21 \mathrm{MPa} / \mathrm{m}$ the crack growth rate is about 50 times higher in air than

- when test in air is started at low $\Delta \mathrm{K}$ values $(13 \mathrm{MPa} \sqrt{\mathrm{m}})$ high initial crack growth rates are also observed but $\mathrm{da} / \mathrm{dN}$ decreases, reaching values identical to that obtained in vacuum for $\Delta \mathrm{K}>20 \mathrm{MPa} \sqrt{\mathrm{m}}$.

The crack path is intergranular with no significant changes between the two test conditions.

This behaviour in air at $750^{\circ} \mathrm{C}$ is still not clearly understood. One possible mechanism to explain this striking slowing down of the crack growth rate in air could be the progressive formation for low $\Delta \mathrm{K}$ of a protective oxide layer limiting the penetration of oxygen at grain boundaries. According to different authors [2,3], this protective effect could be obtained with the formation of $\mathrm{Cr}_{2} \mathrm{O}_{3}$ oxides.

\section{EFFECT OF MICROSTRUCTURE AT $750^{\circ} \mathrm{C}$.}

The importance of creep damage processes at $750^{\circ} \mathrm{C}$ led us to investigate the role of grain size and grain boundary morphology at this temperature. For this study an Astroloy elaborated with rotating electrode powders compacted by extrusion was used. Three different microstructures have been tested in air and in vacuum : a fine-grained material $(20-30 \mu \mathrm{m})$ with smooth grain boundaries, a coarse-grained material (65$90 \mu \mathrm{m})$ with smooth grain boundaries and a coarse-grained material $(45-65 \mu \mathrm{m})$ with serrated boundaries ; procedures used to elaborate such materials are detailed in [4].

\section{Effect of grain size}

Fig. 4 gives the results obtained in air and in vacuum for the fine and coarse-grained material with smooth grain boundaries. These results show that in air the decrease of the grain size leads to a marked detrimental effect on the creep-fatigue resistance (da/dN near 20 times higher for the fine-grained structure).

At a first sight such results appear to be in good accordance with the role of grain size on creep properties. However this point is not confirmed by the results obtained in vacuum since in this environment the fine grained material exhibits a better resistance than the coarse material. That means that the effect of grain size on crack growth under creep-fatigue loading conditions cannot be simply related to creep properties and that the detrimental role of a fine grained structure observed in air at $750^{\circ} \mathrm{C}$ is above all associated with environmental effects as it has been noted previously at $650^{\circ} \mathrm{C}$ [5].

It must be noted concerning the results in air given in Fig. 4 that for the coarse-grained structure the $\mathrm{da} / \mathrm{dN}-\Delta \mathrm{K}$ relationship becomes identical to that obtained in vacuum after the transient period observed at low $\Delta \mathrm{K}$ values. This behaviour is not observed for the fine-grained structure even if in this case the initial $\Delta \mathrm{K}$ level imposed for starting the creep-fatigue test was lower; that shows the higher sensitivity of this structure to the environment.

\section{Effect of grain boundary morphology}

The results obtained in air and in vacuum on the coarse-grained material with swooth and serrated boundaries are plotted in Fig.5. For the testing conditions used here, results in air and in vaccum are identical after the initial transient period in air. Therefore for these structure only the intrinsic properties of the material in the absence of environmental effects can be discussed from Fig. 5. It can be seen that serrated grain boundaries strongly improve crack growth resistance under creep-fatigue at $750^{\circ} \mathrm{C}$. This 
effect is explained by a modification of the propagation processes which are clearly intergranular in air or in vacuum for the material with smooth boundaries and which become mixed (intergranular and transgranular) with serrated boundary structure.

\section{CONCLUSION}

The rates of crack growth under creep fatigue were measured in an Astroloy tested at $650^{\circ} \mathrm{C}$ and $750^{\circ} \mathrm{C}$ in air and in a high vacuum. Tests under vacuum show that the increase in temperature from $650^{\circ} \mathrm{C}$ to $750^{\circ} \mathrm{C}$ accelerates crack growth by favouring creep damage; moreover the fracture path was observed to become intergranular at $750^{\circ} \mathrm{C}$ while it is transgranular at $650^{\circ} \mathrm{C}$.

Environmental effects are already considerable at $650^{\circ} \mathrm{C}$, crack propagation rates being about one order higher in air than in vacuum. At $750^{\circ} \mathrm{C}$ the environmental effects are still stronger (a factor 50 between crack growth rates in air and in vacuum). However at this temeprature we have shown that oxidation effects can be suppressed to obtain the same $\mathrm{da} / \mathrm{dN}-\Delta \mathrm{K}$ relationship as in vacuum. This suppression of environmental effects, which can only been obtained by starting the creep-fatigue test at low $\Delta \mathrm{K}$ levels is accompanied by an atypical da/dN- $\Delta \mathrm{K}$ curve with the crack growth rate decreasing by a factor of about 100 when $\Delta \mathrm{K}$ increases from 13 to $21 \mathrm{MPa} \sqrt{\mathrm{m}}$; This behaviour is assumed to be associated with the formation of a protective oxide layer.

At $750^{\circ} \mathrm{C}$, in air, coarse-grained material has a better resistance than a fine-grained material, but the contrary is observed in vacuum showing the importance of microstructure and environment interactions. Serrated grain boundaries can strongly improve the resistance to crack propagation by changing the fracture processes from intergranular to a mixed propagation mode.

\section{REFERENCES}

[1] J. MENDEZ, P. VIOLAN, M. QUINTARD, G. MARCON, M. MARTY, P. THEVENIN, A. WALDER, "Corrosion-Deformation Interactions. CDI'92" Fontainebleau, October 5-7, 1992, To be published.

[2] E. ANDRIEU, Thèse Ecole des Mines de Paris (1987).

[3] C. MONS and G. MOULIN, "High Temperature Materials for Power Engineering". Kluwer Academic Publishers, The Netherlands, 1990, 1205.

[4] H. LOYER-DANFLOU, M. MARTY, A. WALDER,"Seventh International Symposium on Superalloys", Seven Springs, Champion, PA (USA), September 20-24, 1992.

[5] J. GAYDA and R.V. MINER, Metall Trans., 14A, 1983, 2301.

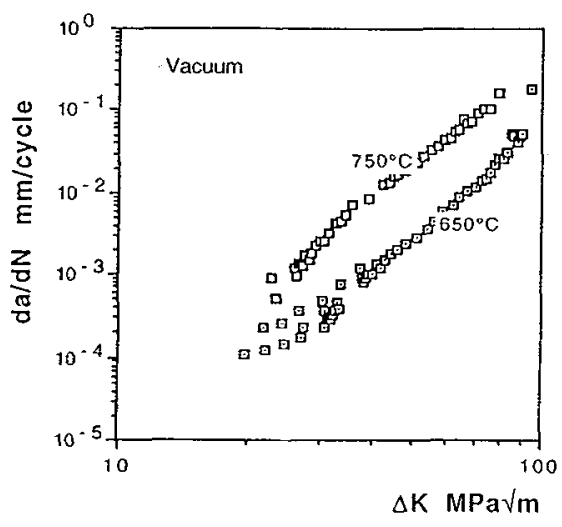

Fig. 1 - Effect of temperature on creep-fatigue crack propagation in vacuum. 


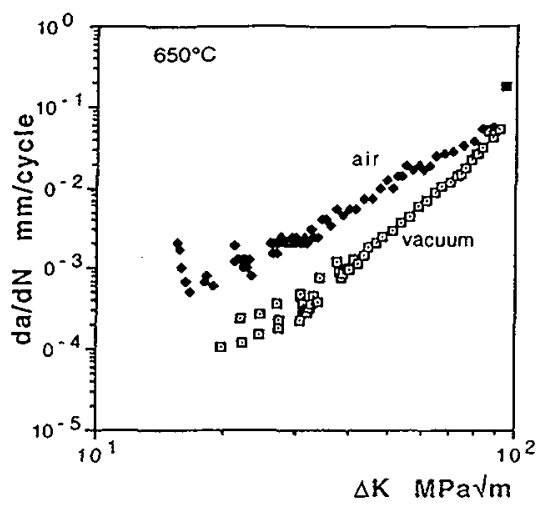

Fig. 2 - Creep-fatigue crack propagation data in air and in vacuum at $650^{\circ} \mathrm{C}$.

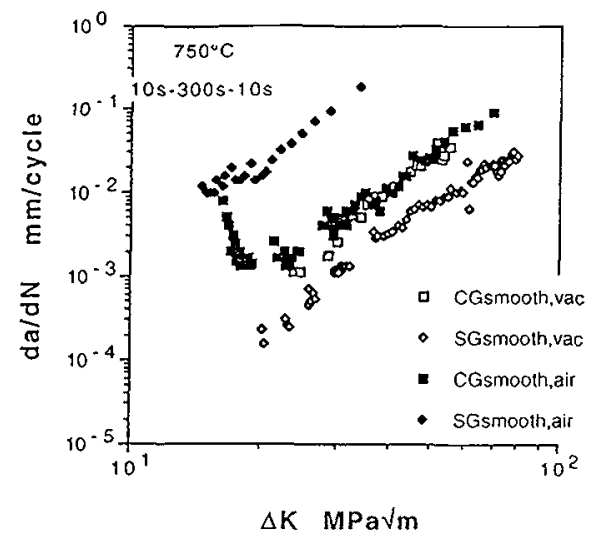

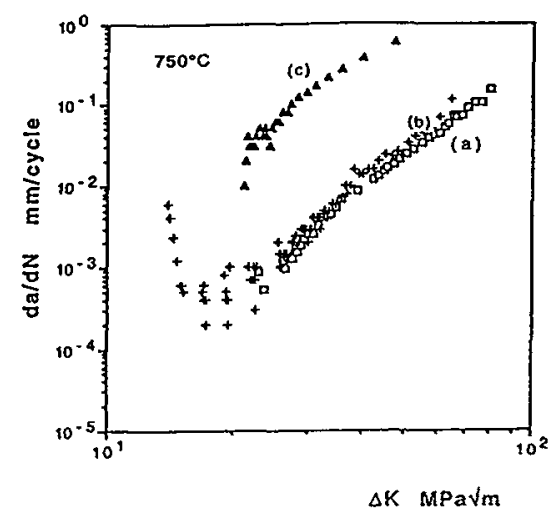

Fig. 3 - Creep-fatigue crack propagation data in air and in vacuum at $750^{\circ} \mathrm{C}$ for different initial $\Delta \mathrm{K}$ levels. a) vacuum, $\Delta \mathrm{K}_{\mathrm{i}}=21 \mathrm{MPa} \sqrt{\mathrm{m}}$; b) air, $\Delta \mathrm{K}_{\mathrm{i}}=13 \mathrm{MPa} \sqrt{\mathrm{m}}$

c) air, $\Delta \mathrm{K}_{\mathrm{i}}=21 \mathrm{MPa} \sqrt{\mathrm{m}}$

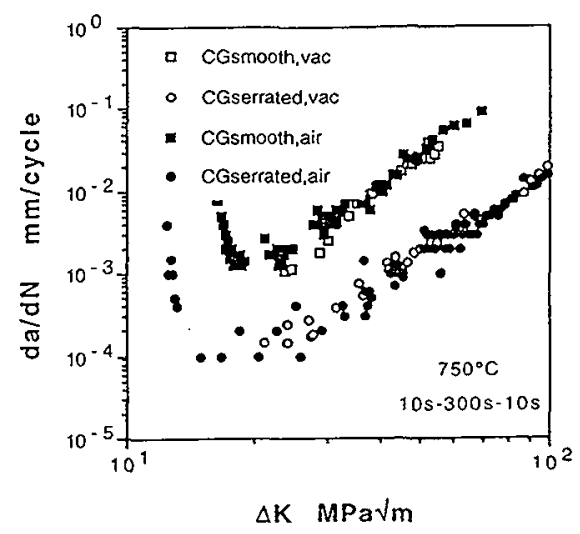

Fig. 4 - Effect of grain size on creep-fatigue crack Fig.5 - Effect of grain boundary morphology on propagation data in air and in vacuum at $750^{\circ} \mathrm{C}$. creep-fatigue crack propagation data in air and in vacuum at $750^{\circ} \mathrm{C}$. 